\title{
47
}

\section{Wearing Two Hats: Lawyers Acting as Mediators}

\author{
Mary Anne Noonet
}

\section{Introduction}

Professional legal bodies promote the use of lawyers as mediators because of their specialist skills, and claim that 'with their skills, training and experience solicitors are ideally placed to be mediators'. ${ }^{2}$ Many lawyers train to be mediators. However, they face a challenge; how to reconcile their various professional responsibilities while wearing two distinct hats: officer of the court and neutral third party. ${ }^{3}$

In this chapter, I discuss issues facing lawyers acting as mediators including clash of values, identification of systemic injustice, parties' access to information and advice and dubiousness of mediators' immunity against legal liability. Initially, I outline models of mediation, the accreditation system of mediators and detail the numbers of lawyers who offer mediation services. In conclusion, three reforms are proposed.

\footnotetext{
1 Professor, Law School, La Trobe University.

2 'Soliciting the Right Kind of Mediator' (2005) 79(4) Law Institute Journal 22 (News section).

3 The wearing two hats analogy is also used for lawyers who act as advocates and negotiators (see Bobette Wolski, Skills, Ethics and Values for Legal Practice (Lawbook Co, $2^{\text {nd }}$ edn, 2009) 116) and in-house counsel who are also the company secretary (Emilios Kyrou, 'Legal Professional Privilege for General Counsel Wearing Two Hats' (2000) 5 Law Society Journal 42).
} 


\section{Mediation and Accreditation}

Courts and tribunals require disputing parties to use alternative dispute resolution (ADR) processes often as a condition precedent to accessing these forums. This integration is reinforced in legislation; for example, an objective of the Civil Dispute Resolution Act 2011 (Cth) is to ensure people take genuine steps to resolve disputes before instituting civil proceedings. Mediation is the most common form of ADR utilised in all forms of litigation.

In practice, there is significant variation in the context and process of mediations. There are at least four models of mediation: facilitative, evaluative, settlement and transformative. The facilitative model underpinned early developments in community mediation; however, with the increased use of court-related mediation, the settlement and evaluative models are commonly used in practice. The models are not necessarily distinct alternative forms of practice but rather 'tendencies in practice'. Within any one mediation, different modes might be adopted at different times. ${ }^{4}$

With the exponential growth in numbers of mediators in the 1990s, the desire to ensure quality and accountability in mediation practice led to the development of accreditation and practice standards for Australian mediators. The National Mediator Accreditation Scheme (NMAS) became operative in January 2008. In 2017 there were 3,216 mediators accredited by Recognised Mediation Accreditation Bodies (RMABs). ${ }^{5}$

Mediators who are (voluntarily) accredited must comply with the Approval Standards as well as the Practice Standards. The standards specify practice and competency requirements for mediators; inform participants and others about what they can expect of the mediation process and mediators; set out minimum practice requirements and allows mediators to develop or comply with additional standards if they so wish. ${ }^{6}$ The standards provide that where a mediator practices under a legislative framework,

$4 \quad$ Laurence Boulle, Mediation: Principles, Process and Practice (LexisNexis, $3^{\text {rd }}$ edn, 2011) 43-45.

5 A list of accredited mediators is available on the Mediator Standards Board website: www.msb. org.au/.

6 National Mediator Accreditation System, Part III, Practice Standards (2015). 
this prevails over any inconsistency with the standards. Additionally, the standards state a mediator must adhere to the ethical code prescribed by the professional organisation of which they are a member. ${ }^{7}$

\section{Lawyers as Mediators}

The legal profession was initially sceptical of the expansion in ADR which was in part a response to critiques of the traditional adversarial legal dispute system, including criticism of the dominant and controlling role of lawyers. Some lawyers, however, quickly embraced mediation within the scope of their professional services. For instance, in 1989, Lawyers Engaged in Alternative Dispute Resolution (LEADR) was formed to promote the use of alternative dispute resolution instead of litigation. ${ }^{8}$

Since that time, many lawyers, both barristers and solicitors, have trained in mediation. Lawyers' professional organisations (including Law Societies in Victoria, South Australia, Western Australia, Queensland and New South Wales, and Bar Associations in Queensland South Australia and Victoria) accredit lawyers to be mediators and also have a responsibility to monitor the standards. The legal professional associations actively promote the benefits of engaging a mediator with lawyers' skills. In court-annexed mediations, the mediator chosen will invariably be a legal practitioner. Lawyers' professional indemnity insurance policies now consider mediation to be a 'legal service' and lawyers acting as mediators are insured against liability in this work. ${ }^{9}$

The professional bodies for both solicitors and barristers have dedicated directories for the public to identify lawyers who are also mediators. An indication of numbers of lawyers who also mediate is that 10.58 per cent (213) of barristers ${ }^{10}$ and 1 per cent (101) of solicitors are accredited mediators in Victoria. Law firms are also promoting a specific focus on providing dispute resolution services. For example, in Victoria:

\footnotetext{
$7 \quad$ Ibid. cll 1.3 and 8.3 .

8 LEADR opened its organisation to non-lawyers in 1990s and recently amalgamated with the Institute of Arbitrators and Mediators to form the Resolution Institute: www.resolution.institute/.

9 For example, see Law Society of New South Wales, Guidelines for Mediators Who Act as Mediators, www.lawsociety.com.au/resources/adr/MediatorsPanel/index.htm.

10 Victoria Bar, Barrister's Directory, www.vicbar.com.au/barrister-directory/mediator-arbitratorsearch/search-for-a-mediator and Law Institute of Victoria, www.liv.asn.au/Mediators (viewed 21 April 2017).
} 
McFarlane Legal: Dispute Resolution is a law firm that practises solely in the area of resolving disputes using alternative dispute resolution techniques - predominantly mediation, arbitration and facilitation. 'We are experts in the area and we have an enviable track record of resolving the great majority of disputes that come before us'. ${ }^{11}$

There are separate codes of conduct for lawyers and accredited mediators but, as the National Mediator Standards indicate, the lawyer's professional obligations prevail over any conflicting mediator standards. The lawyers' code of professional conduct is designed 'to assist solicitors to act ethically and in accordance with the principles of professional conduct established by the common law and these rules'. ${ }^{12}$ In this code the definition of 'court' includes 'an arbitration or mediation or any other form of dispute resolution'.

Some state law societies have adopted specific guidelines for solicitors who act as mediators. ${ }^{13}$ Similarly, the Law Council of Australia has approved Ethical Standards for Mediators that are intended to serve as a guide for the conduct of mediators, to inform the mediating parties of what they should expect, and to promote public confidence in mediation as a process for resolving disputes. ${ }^{14}$

\section{Issues for Lawyers Who Act as Mediators}

Comparing the usual practice of lawyering with mediation practice, there is a fundamental variance between a rights versus interests-based approach. 'Interest-based processes are concerned with finding solutions that meet the needs and interests of the parties involved. Rights-based processes are concerned with determining outcomes based on rights, rules and law.' ${ }^{15}$ The National Alternative Dispute Resolution Advisory Council (NADRAC) noted the 'alternative' in ADR sometimes refers to 'interest-based' dispute resolution processes as an alternative to 'rights-

\footnotetext{
11 www.mcfarlanelegal.com.au/.

12 Legal Profession Uniform Law Australian Solicitors' Conduct Rules 2015, cl 3.1.

13 For example, Law Society of NSW, above $\mathrm{n} 9$.

14 Law Council of Australia, Ethical Standards for Mediators, Updated Version, August 2011, learnedfriends.com.au/getmedia/b72ee6c5-cbf4-4c8f-b170-cd7bc66fd5cf/Walker_EthicalGuidelines.aspx.

15 National Alternative Dispute Resolution Advisory Council, ADR Terminology: A Discussion Paper (2002) 10. The interest-based approach to negotiation was popularised in Roger Fisher and William L Ury, Getting to Yes: Negotiating Agreement Without Giving In (Penguin Press, 1981).
} 
based' processes. Additionally, the core values underpinning mediation neutrality, self-determination, voluntariness and confidentiality - can pose challenges for the mediations lawyers are often involved in. For example, with the increased use of court-directed mediation, parties' 'voluntary' participation is compromised. Similarly strict adherence to concepts of confidentiality, neutrality and self-determination are the focus of critical analysis. ${ }^{16}$

Lawyer-mediators face ethical challenges when they have to choose between competing values. ${ }^{17}$ In a qualitative research project exploring ethical and practical issues in mediation, mediators provided examples of ethical issues from their own experience:

- confidentiality of settlement in a mediation involving an abuse survivor and a church organisation raising questions about the preservation of the victim's legal rights;

- tension between the mediator's obligations to the parties and larger public interest questions, e.g. if there's a point of law that needs clarifying;

- parties about to enter an agreement that is outside the law;

- lack of good faith and deceptive conduct by one party;

- capacity of parties (e.g. one party had an intellectual disability and the proposed agreement was significantly different from a likely hearing outcome); workplace bullying dispute and victim was too stressed to be in the same room as the other party;

- inequality and power differentials, particularly where one party is uninformed or misinformed;

- information received in private session about potential bankruptcy of the party. ${ }^{18}$

The examples illustrate how mediators have to grapple with complex ethical conundrums.

16 Mary Anne Noone and Lola Akin Ojelabi, 'Ethical Challenges for Mediators: An Australian Perspective' (2014) 45 Washington University Journal of Law and Policy 145.

17 Boulle, above n 4; Julie MacFarlane, 'Mediating Ethically: The Limits of Codes of Conduct and the Potential of a Reflective Practice Model' (2002) 40 Osgoode Hall Law Journal 49; Patricia Marshall 'The "Partial" Mediator: Balancing Ideology and the Reality' (2010) 11(8) ADR Bulletin 176; Rachel Field, 'Mediation Ethics in Australia: A Case for Rethinking the Foundational Paradigm' (2012) 19 James Cook University Law Review 41.

18 Noone and Akin Ojelabi, above n 16. 
Professional standards for lawyers and mediators are designed to assist an individual practitioner in resolving and avoiding ethical dilemmas. However, these do not address all ethical issues and they sometimes contain competing or conflicting provisions and values. Additionally the mediators' standards can clash with lawyers' codes of conduct. ${ }^{19}$ The lawyer's duty that is most challenged, when lawyers act as mediators, is their duty to the court.

When an individual is admitted to legal practice in Australia they become an officer of the court. Consequent duties include not engaging in abuse of process or bringing the administration of justice into disrepute. ${ }^{20}$ The conduct of lawyers who act as mediators might be called into question when the outcomes of mediations are seen to be unjust, unfair, and illegal or expose systemic issues.

For lawyers acting as mediators, the following issues are accentuated by their officer of the court status:

- Does a lawyer-mediator have a greater responsibility to ensure just and lawful outcomes?

- What responsibility does the lawyer-mediator have for ensuring parties are well informed, especially about rights they may be foregoing?

- Should lawyer-mediators breach confidentiality when it is in the public interest or there is systemic abuse? ${ }^{21}$

- Can lawyer-mediators seek immunity in their Agreements to Mediate?

Lawyers acting as mediators should be exemplars, guaranteeing their mediation practice facilitates access to justice rather than impedes it. A requirement that lawyer-mediators ensure parties, who are foregoing legal entitlements or rights, are aware this is the case, and are encouraged to seek information and legal advice, is needed. The duty to administration of justice should prevail and, when lawyer-mediators recognise that

19 Ellen Waldman (ed), Mediation Ethics: Cases and Commentaries (Jossey-Bass, 2011); Noone and Akin Ojelabi, above n 16.

20 Legal Profession Uniform Law 2014 s 2.2.25; Gino Dal Pont, Lawyers' Professional Responsibility (Thomson Reuters, 2013) 536.

21 Dominik Leimguber, 'Confidentiality, Public Interest and the Mediator's Ethical Dilemma' (2013) 24 Australasian Dispute Resolution Journal 187; Mary Anne Noone, 'ADR, Public Interest Law and Access to Justice: The Need for Vigilance' (2011) 37(1) Monash University Law Review 57. 
the agreement available to the parties is unfair, they have an ethical responsibility not to be complicit in the acceptance of the injustice without taking some action. ${ }^{22}$

In 2000, the Australian Law Reform Commission (ALRC) noted several factors that may indicate when ADR processes are unsuitable for resolving a dispute and court adjudication is more suitable. They were:

- when a definitive or authoritative resolution of the matter is required for precedential value;

- when the matter significantly affects persons or organisations who are not parties to the ADR process;

- when there is a need for public sanctioning of conduct or where repetitive violations of statutes and regulations need to be dealt with collectively and uniformly;

- when parties are unable to negotiate effectively themselves or with the assistance of a lawyer;

- in family law matters, where there is a history of family violence. ${ }^{23}$

The Victorian Parliament Inquiry into Alternative Dispute Resolution recommended ADR providers publish, in a de-identified form, regular case studies and reports on systemic issues and any other issues of public interest that arise as part of their ADR processes. ${ }^{24}$ Recommendations aimed at improving the 'appropriateness' of ADR services included training for ADR practitioners on cross-cultural differences and power imbalances, recognition of the difficulties of people with language difficulties and limited literacy, as well as the provision of information and legal advice prior to involvement in ADR.

Another challenging area for lawyers acting as mediators is conducting the process in a way which is fair, even-handed, objective and unbiased. Lawyers normally work in a partisan way where they seek to advance the interests of only one party in a dispute. Additionally lawyers may be chosen as mediators by parties, with the expectation, based on promotional

22 Hilary Astor and Christine Chinkin, Dispute Resolution in Australia (Butterworths, $2^{\text {nd }}$ edn, 2002) 230 .

23 Australian Law Reform Commission, Managing Justice: A Review of the Federal Civil Justice System (ALRC, 2000) [6.62].

24 Parliament of Victoria, Law Reform Committee, Inquiry into Alternative Dispute Resolution and Restorative Justice: Final Report of the Victorian Parliament Law Reform Committee (Victorian Government Printer, 2009) 84. 
material, that they bring their expertise to the process and will perform an evaluative function of liability and other issues. ${ }^{25}$ NADRAC has suggested that practitioners' responsibilities include identification and disclosure of 'any existing or prior relationship between the practitioner and the parties; any interest in the outcome of the dispute; any present or future conflicts of interest; any values, experience or knowledge that may prevent a practitioner from acting impartially'. ${ }^{26}$ When lawyers act as mediators, the concern for impartiality and neutrality is accentuated. It is generally accepted that legal practitioners should not act as a mediator in a case involving their own client although this is not specifically prohibited. ${ }^{27}$ Certainly they should be experts in identifying conflicts of interests but until recently their broad knowledge and skills have been embedded in an adversarial approach. ${ }^{28}$ These skills do not easily transfer to mediation and additional training is required. The legal profession has recognised this concern with impartiality and sought to address it in the codes of conduct for lawyer-mediators in both New South Wales and Queensland. ${ }^{29}$

The promotion of lawyers as mediators by their professional organisations for 'their special skills, training and experience' implies a level of knowledge and expertise above that of other mediators. Lawyer-mediators are likely to be held to a higher standard of care than non-lawyer-mediators. ${ }^{30}$ Anecdotally, many barristers undertake evaluative or settlement-focused mediations. A series of cases, recently summarised by Spencer, 'disclose an apparent lack of clarity by parties, lawyers and mediators as to the status of the parties' intentions to be bound by an agreement that is subject to the execution of formal contract'. ${ }^{31}$ In summarising these cases Spencer raises the spectre of mediator liability as he argues that in all the cases the lawyers and the presiding mediator should 'have anticipated the issues that ultimately arose for adjudication by the courts'. It seems likely that in

25 Boulle, above n 4, 221.

26 National Alternative Dispute Resolution Advisory Council, Maintaining and Enhancing the Integrity of ADR Processes: From Principles to Practice Through People (NADRAC, 2011).

27 Law Council of Australia, above n 14, cl 3.

28 Christine Parker and Adrian Evans, Inside Lawyers' Ethics (Cambridge University Press, $2^{\text {nd }}$ edn, 2014) 228-36.

29 Boulle, above n 4, 490: Queensland Law Society Standards of Conduct for Solicitor Mediators, s 4.1 and NSW Law Society Guidelines for Solicitors who Act as Mediators, s 5.1.

30 Boulle, above n 4, 723.

31 David Spencer, 'Landing in the Right Class of Subject to Contract Agreements' (2015) 26 Australasian Dispute Resolution Journal 75. 
the near future, particularly if the mediator is a lawyer who should know about the need to be clear about the intention to be bound, that person may also be joined as a third party to litigation:

It seems that the eagerness to conclude mediation caused critical matters not to be negotiated and therefore left the intention of parties immediately bound in doubt ... Some mediators, many of whom in court-annexed mediation schemes are legally trained, fail to establish the parties' intentions to be immediately bound. Parties can be forgiven, since they are not legally trained; however, lawyers and mediators should know better. ${ }^{32}$

A related issue for lawyer-mediators is the use of immunity clauses in agreements to mediate. This practice by lawyers is questionable both legally and ethically. ${ }^{33}$ It is common practice for mediators to get the parties to sign an Agreement to Mediate, especially when it is not courtrelated mediation. Lawyers' professional associations provide precedent Agreements to Mediate to their members. These agreements routinely contain a clause where the parties grant immunity from liability to the mediator. For example:

The mediator will not be liable to a party for any act or omission in the performance of the mediator's obligations under this agreement unless the act or omission is fraudulent. ${ }^{34}$

When the mediator is a legal practitioner, there is real doubt about the appropriateness and lawfulness of such exclusion clauses. At common law, lawyers cannot, by means of an exclusion clause in the retainer agreement, reduce their standard of care or exempt themselves from liability for default in the performance of their professional responsibilities. ${ }^{35}$ In Victoria, lawyers were, until recently, also legislatively prohibited from contracting out of liability to their clients unless this is permitted by other legislation such as the professional standards scheme. ${ }^{36}$ If a lawyer does enter into such an agreement, it is said to be void. ${ }^{37}$

32 Ibid. 84.

33 Mary Anne Noone, 'Liability Matters for Lawyer Mediators' (2007) 81(10) Law Institute Journal 52.

34 Law Society of NSW, Agreement to Mediate, cl 25.

35 Dal Pont, above n 20, [5.180]; see also Wilkinson v Feldworth Financial Services Pty Ltd (1998)

29 ACSR 642.

36 Legal Profession Act 2004 (Vic) s 7.2.11 (2).

37 Ibid. s 7.2.11 (3). 
Three policy reasons for prohibiting lawyers from limiting their liability are: public confidence in lawyers and the justice system would be diminished if lawyers could avoid actions for negligence by having a broadly worded exclusion clause in the retainer agreement; the public service aspect of professionalism is inconsistent with the notion that lawyers can exclude liability to their clients; and by including an exclusion clause in the retainer, the lawyer is putting their own interests above their clients and this is a conflict of interest and duty. ${ }^{38}$ Given that mediation is accepted as one of the services lawyers can provide, these same reasons should apply to the Agreement to Mediate used by lawyers.

Mediation is a legal service offered by many lawyers and the relevant legal professional indemnity insurance schemes provide cover for mediations conducted by lawyers if they form part of the normal work of the legal practice. ${ }^{39}$ There is a major contradiction between the required unlimited liability of legal practitioners and the limited liability lawyers seek when they work as mediators. It is illogical for lawyers simultaneously to be permitted to sign agreements containing exclusion clauses. The public policy reasons prohibiting exclusions clauses generally in a lawyer's retainer apply equally in the context of a lawyer acting as mediator signing an agreement with the parties. This is the case especially if one or more of the parties are not legally represented.

Lawyers who act as mediators should be concerned about the lawfulness of exclusion clauses in Agreements to Mediate. Lawyers acting as mediators must fulfil their professional responsibilities and not seek immunity in mediation. In the context of the general critique of mediators' immunities, lawyers should be enhancing the administration of justice by leading the way and removing exclusion of liability clauses from their Agreements to Mediate.

\section{Conclusion}

Lawyers who act as mediators face challenges when wearing the two distinct hats of lawyer and mediator. As officers of the court, lawyers do have additional responsibilities which cannot be put aside when they act as mediators. Lawyers who are mediators should be exemplars of ethical

38 Dal Pont, above n 20.

39 Confirmed by representative of Victoria’s Legal Practitioners Liability Committee, June 2015. 
and appropriate mediation practice. They should be impartial, treat the parties fairly without bias, ensure the parties have access to information and advice to realistically assess the proposed mediated agreement and avoid all conflicts of interest. Additionally, lawyer-mediators should not seek to limit their liability by the use of exclusion clauses in Agreements to Mediate.

To address some of the concerns raised in this chapter, three specific suggestions for inclusion in the various codes of conduct for lawyermediators are:

- a requirement to ensure parties are aware of legal rights (access to information and/or advice) before agreeing to forego them in the negotiated settlement;

- procedures established for mediators to report systemic issues that they identify in disputes they mediate; and

- prohibition on immunity from liability in mediations. 
This text is taken from New Directions for Law in Australia: Essays in Contemporary Law Reform, edited by Ron Levy, Molly O’Brien, Simon Rice, Pauline Ridge and Margaret Thornton, published 2017 by ANU Press, The Australian National University, Canberra, Australia. 